\title{
Yazlım Projelerinde Fazla Mesainin Proje Ekibi ve Projenin Yönetimine Etkisi
}

\author{
Effects of Overtime in Software Projects on Project Team and Project Management
}

\author{
Merve PINAR $^{1}$ (D), Büşra BÜYÜKTANIR ${ }^{1,2}$ (i) Şura EMANET ${ }^{1}$ (i) Buket DOĞAN $^{1}$ \\ ${ }^{1}$ Marmara Üniversitesi, Teknoloji Fakültesi, Bilgisayar Mühendisliği Bölümü, 34722, Kadıköy / İSTANBUL \\ ${ }^{2}$ Altınbaş Üniversitesi, Mühendislik ve Doğa Bilimleri Fakültesi, Yazılım Mühendisliği Bölümü, 34217, \\ Bağcllar/ISTANBUL
}

\begin{abstract}
$\ddot{\mathbf{O z}}$
Yazılım projelerinde, çalışma takvimine göre projenin belirlenen sürede yetişmeme durumu ortaya çıkabilir. Böyle durumlarda fazla mesai yapılması çözüm olarak görülmektedir. Fakat çalışma saatlerinin artmasının proje sonucuna etkisi belirsizdir. Bu çalışmada fazla mesainin, çalışanlar ve proje üzerindeki etkilerinin incelenmesi için çalışanların fazla mesai ile çalışma saatlerinin arttırılması konusundaki düşüncelerini almak amacıyla, çevrimiçi katılım sağlanarak cevaplanacak şekilde anket hazırlanmıştır. 2019 Kasım ayı boyunca, çevrimiçi ortamda aktif olan ve 34 sorudan oluşan ankete, yazılım projelerinde görev alan 180 kişi katılmıştır. Çalışmanın sonucunda, fazla mesaiden dolayı çalışanların dinlenemedikleri, fiziksel sağlık sorunlarının ortaya çıktığı ve sosyal yaşamlarının olumsuz etkilendiği ortaya çıkmıştır. Ayrıca art arda yapılan fazla mesailerin, çalışanların mesai saatleri içerisindeki üretkenliğini de olumsuz etkilediği belirlenmiştir.
\end{abstract}

Anahtar Kelimeler: Fazla Mesai, Yazılım Mühendisliği, Yazılım Projeleri, Yazılım Kalitesi, Proje Yönetimi

\begin{abstract}
In software projects, it may happen that the project does not catch up within the specified time according to the work schedule. In such cases, overtime work is considered a solution. However, the effects of the increase of working hours on the result of the project are uncertain. In this study, a survey was prepared to be answered by providing online participation in order to get the opinions of the employees about increasing overtime and working hours to examine the effects of overtime on the employees and the project. During November 2019, 180 people who took part in software projects participated in the survey, which is active online and consists of 34 questions. As a result of the study, it appeared that employees could not rest due to overtime, physical health problems occured and their social lives were negatively affected. In addition, successive overtime work has been found to negatively affect employees' productivity during working hours.
\end{abstract}

Keywords: Overtime work, Software Engineering, Software Projects, Software Quality, Project Management

\section{GİRIŞ}

Bir yazılım projesi geliştirme süreci başladığında, öncelikle planlama yapılarak projenin hedeflerinin gerçekleştirilmesi ve müşterinin taleplerinin karşılanması amaçlanır. Bunun için hangi yöntemle geliştirileceği, tamamlanması gereken işleri, gerekli olan kaynakları ve kısıtlamaları belirlemek gerekir. Planlama aşamasında öngörüler ile kaynak ve zaman planlaması yapılsa bile çeşitli sebeplerden dolayı proje planlandığı takvim ve gerçekleştirim hedeflerini yakalayamayabilir. Çünkü yazılım geliştirme projelerinde doğal bir belirsizlik vardır. Yeni teknolojiler, yeni iş süreçleri, yeni proje üyeleri ve diğer birçok çevresel faktör üzerindeki belirsizlik, projeyi ve proje ekibini etkiler. Örneğin; kapsam kayması ve gereksinimlerdeki değişimler proje çıktılarında, proje bütçesinde veya proje planlarında sapmalar oluşturabilir. Kalite, işlevsellik ve bütçe ile ilgili endişeler proje ekibi için önemli olmakla birlikte, proje takvimindeki sapmalar proje ile ilgili dikkat edilmesi gereken en kritik ögelerdir [1]. Örneğin; yazılım projelerinde, proje kilometre taşı tarihi yaklaş̧ı̆̆ında, önemli bir dönüm noktası tarihinden önceki dönemlerde proje ekibinin karşılaştı̆̆ ek bir baskı durumu söz konusu olmaktadır. Kilometre taşı tarihi yaklaşırken, proje ekibi tarih gelmeden önce artan bir faaliyet hacmini tamamlamaya çalışırken, yüksek kalitede proje çıktıları üretmeye de devam etmek durumundadır. Projede geciken bir kilometre taşı ise, proje ekibine daha yüksek iş yükleri ve oluşabilecek hatalar ile ilgili kaygıların oluşmasına neden olabilir [1]. Bu durumda; planlanan zamanı güncelleyerek daha önceden belirlenen takvimi ertelemek, ekibe yeni kaynak eklemek veya çalışanların fazla mesai yapması gibi çözümler bulunabilir [2]. Bu çözümlerin süreçleri yavaş ilerlediği ve ekibe alınmak istenen üyenin adaptasyon süreci olduğu için çoğu kez daha hızlı çözüm olarak düşünülen fazla mesai yapma yoluna gidilmektedir. Öte yandan ekip üyeleri projeye hakim olduğu için, dışa bağımlılığı az ve kolay bir çözüm 
olan fazla mesai ilk akla gelen çözüm olarak düşünülür [3].

Yazılım süreçleri insan odaklı süreçler olduğu için çalışanların fazla mesaiden nasıl etkilendiklerinin belirlenmesi yazılım projelerinin başarılı ilerlemesi açısından önemli bir konudur. Literatürde fazla mesainin proje ekibinin dolayısıyla projenin verimliliği ve çalışanlar üzerinde olumsuz etki ettiğine dair çalışmalar [4, 5] yer almaktadır. Fakat yazılım geliştirme dikkat, üretkenlik ve motivasyon gerektiren bir süreç olduğu için fazla mesainin projeye ne şekilde etki edeceğinin belirlenmesi gerekmektedir. Yazılım projelerinde fazla mesai faaliyetleri, yazılım geliştirmeyi insan merkezli bir faaliyet olarak ele aldığımızda da önemli bir konudur. Bu faaliyetlerden etkilenen yazılım geliştiricilerin hem fiziksel hem de psikolojik olarak etkilendiğine dair farklı ülkelerden çalışmalar bulunmaktadır [6]. Küresel yazılım dünyasında her gün giderek daha fazla önem kazanan ülkemizdeki yazılım çalışanlarının fazla mesaiden nasıl etkilendiklerine dair literatürde sınırlı çalışma [7] yer almaktadır. Her dönem ve her ülkenin farklı çalışma kültürü olduğundan ve fazla mesaiden çalışanların etkilenme durumları da farklılık göstereceğinden dolayı bu alanda ülkemizdeki durumun ortaya konması önemlidir. Bu amaçla, bu çalışma ülkemizde yazılım alanındaki çalışanların fazla mesaiden ne şekilde etkilendiklerini ortaya koymayı amaçlamaktadır. Çalışmanın sonuçları; yazılım proje yöneticileri ve takım liderlerinin yazılım projelerinde daha verimli görev planlaması yapmasını sağlarken, rekabet gücü yüksek yazılımlar üretilmesi için daha doğru kararlar almasını da sağlayabilecek çıktılar üretecektir.

Bu çalışmada; yazılım alanında yukarıda önemi belirtilen; ülkemizdeki yazılım çalışanlarının fazla mesai konusundaki görüşlerinin ortaya konması için hazırlanan anket kullanılarak, fazla mesainin verimliliğe, üretkenliğe, kaliteye ve kişisel bireysel hayatlarına olan etkilerinin ortaya konması sağlanmaktadır.

\section{1. İlgili Çalışmalar}

Fazla mesai, iş kanununa göre çalışanlar için haftalık belirlenen saati aşan çalışmalardır. Yazılım projelerinde, proje belirlenen takvimde bitmediği zaman ilk akla gelen çözümlerden biri fazla mesaidir. $\mathrm{Bu}$ yüzden fazla mesainin yazılımdaki etkisini araştırmak güncel bir konudur. Literatür çalışmalarında fazla mesainin proje olduğu gibi proje çalışanlarının sosyal ve kişisel hayatına da olumsuz etki ettiği gözlemlenmiştir. Öte yandan çalışmada kullanılan metodolojinin fazla mesaiyi etkilediği ortaya çıkmıştır. İlgili çalışmalar aşağıdaki gibidir.

Türkdoğan ve arkadaşları tarafından yapılan çalışmada, fazla mesainin verimliliği olumsuz yönde etkilediği ve fazla mesai yapmanın, mesai saatleri dışındaki planlı olarak yapılması gereken durumlar dışında fazla mesai yapmamaktan daha kötü bir seçim olduğunu belirtmişlerdir. Ayrıca yaptıkları çalışma, fazla mesainin fiziksel ve psikolojik sağlı sorunları olasılığını arttırdığını bunun yanında aile ve sosyal yaşamlarını da olumsuz yönde etkilediğini göstermiştir [7].

Fazla mesainin proje üzerindeki etkilerini inceleyen Chris ve Frank yaptıkları bir çalışmada yazılım projelerinin geliştirilme sürecinde Scrum metodolojisi kullanıldığında, proje çalışanlarının çalışma takvimine uygun hızda hareket ettiği için fazla mesai sürelerinin azaldığını görmüşlerdir. Buna paralel olarak müşteri memnuniyetinde de artış görülmektedir [8].

Kusurları önlemenin onları düzeltmekten çok daha az zaman aldığı ve maliyetinin daha düşük olduğu bilinmektedir. Extreme Programming'in kurucularından Jeffries tarafindan yayınlanan bir makalede hataları tespit etmenin ve düzeltmenin büyük sistemler için en pahalı maliyet unsuru olduğu ve diğer tüm faaliyetlerden daha fazla zaman aldığı belirtilmiştir. Ayrıca son yapılan çalışmalar; yorgun halde ve stres altında çalışan programcıların çok büyük hatalar yapma olasılığının iki katına çıktığını, küçük hatalar yapma olasılığının çok daha yüksek bir orana sahip olduğunu göstermektedir [9].

Sıkışıklık Zamanı (Crunch Time) oyun endüstrisinde kullanılan ve aşırı yoğun zamanları tarif eden bir terimdir. Petrolio'ya göre sıkışıklık zamanı genellikle nihai ürün ortaya çıkmadan önceki dönemi ifade etmektedir. Çoğu araştırma oyun sektöründe sıkışıklık zamanının gerekli olduğunu ve bunun bir sektör kültürü olduğunu düşünmektedir. Ancak fazla mesaiden kaynaklı uykusuzluk, sektör çalışanlarının ruh sağlığını ve kişisel ilişkilerini olumsuz yönde etkilemektedir. Çalışanlar, proje sonunda meydana gelen ürüne kişisel bir yatırım yaptıkları için, kötü sonuçlanırsa kendilerini suçlamaktadır. $\mathrm{Bu}$ durumlar, kişilerin sektör değiştirmesine sebep olmaktadır. Çevik geliştirim prensipleri kullanılarak proje yönetilmeye başlandığında, bu zaman azalmış ama yine de devam etmiştir [10].

Akula ve Cusick yaptıkları çalışmada yoğun bir planlama ile yazılım kalitesi üzerindeki negatif etkisi arasında Şekil 1'de görüldüğü gibi bir bağlantı kurmuşlardır. Yoğun planlamanın fazla mesaiye sebep olduğunu tespit etmiş ve fazla mesaiye bağlı olarak stresin arttığını gözlemlemişlerdir. Stres, çalışan üzerinde olumsuz etkilerini göstermiş ve yazılımda hatalara sebep olmuştur.

\section{Yoğun planlama $\longrightarrow$ Fazla mesai $\longrightarrow$ Stres $\longrightarrow$ Hata \\ Şekil 1. Yoğun planlama ile yazılım kalitesinin bağlantısı}

Zaman yönetimi, teknoloji ve verimlilik üzerine danışmanlık veren kişisel üretkenlik uzmanı Duncan'a 
göre stresin sebebi birçok faktör olabilir. Düzensizlik, net olmayan hedefler, çok fazla kişisel telefon görüşmesi, ayrık süreçler, belli bir iş rutinin olmaması, zayıf planlama, erteleme, odaklanma ve eğitim eksikliği stres sebeplerinin bazılarıdır [9].

Fazla mesainin kişisel etkileri incelendiğinde ise aşırı veya zorunlu mesai yapmanın sadece programcı için değil programcının ailesi ve sosyal hayatı için de rahatsız edici bir durum olduğu görülmüştür. Bu durum aile bireylerinin çalışmasını olumsuz yönde etkileyebildiği gibi, rol çatışması ortaya çıkartabilir. Aşırı iş yükü, ev sorumlulukları ve çocuk bakımı için eşit olmayan bir iş bölümüne sebep olabilir. Ek olarak, proje baskısından kaynaklanan huzursuzluk veya yetersiz uykudan kaynaklanan huzursuzluk, küçük sorunların bile genellikle çatışmaya yol açmasıyla sonuçlanan hassas bir ruh hali oluşturabilir [1].

Nishikitani ve arkadaşları tarafından gerçekleştirilen çalışmada, fazla mesai, uyku süresi ve çalışılan iş türünün çalışanların fiziksel ve zihinsel durumları üzerindeki etkilerini araştırmak için bir bilişim teknolojisi şirketinde yazılım mühendisi olarak çalışan 377 kişi üzerinde kesitsel bir çalışma yürütülmüştür. Fazla mesai yapmanın psikofiziksel sonuçları, Hamilton Depresyon Ölçeği (HDS), Duygu Durum Profili (POMS), majör fiziksel semptomlar ve fazla mesai çalışma süre verileri ile belirlenmiştir. Tek değişkenli bir analizde, fazla mesainin HDS skorları, POMS öfke-düşmanlık skorları ve toplam fiziksel semptom sayısıyla önemli ölçüde ilişkili olduğu görülmüştür [11].

Farklı bakış açısına rastlanan bir çalışmada hem proje yöneticisi hem de ekip üyesi olan bir çalışan, projeyi daha önce sunmak ve yönetimi etkilemek için 16 saat/gün çalıştığını ve iyi bir rol model olduğunu düşünmektedir. Ayrıca takım arkadaşlarının da fazla mesaiye kalmasını sağlayarak gelir elde etmeleri konusunda katkı sağladığına inanmaktadır [1].

Literatürde fazla mesainin çalışanlar üzerindeki etkilerini konu alan çalışmalar incelendiğinde fazla mesainin, proje sonucuna, çalışanların fiziksel ve zihinsel durumlarına, sosyal ve özel hayatlarına etkilerinden bahseden farklı çalışmalar bulunmaktadır. $\mathrm{Bu}$ çalışmada ise yazılım projelerinde yer alan çalışanlara fazla mesai etkilerini ölçmek için anket soruları yöneltilmiş ve bu etkilerin mevcut durumunun devam ettiği görülmüştür. Fazla mesainin proje ve proje çalışanları üzerinde olumsuz bir etki oluşturduğu ortaya çıkmıştır.

\section{MATERYAL VE YÖNTEM}

Yazılım proje sürecinde, öngörülen veya görülemeyen aksamalardan dolayı projenin yetişmemesi durumu ortaya çıkmaktadır. Böyle bir durumda fazla mesai düşünülen çözümlerden biridir. Bu çalışma ile fazla mesainin çalışanlar ve proje üzerindeki etkilerinin ortaya çıkarılması amaçlanmaktadır. $\mathrm{Bu}$ amacı gerçekleştirmek için ilk olarak yazılım projelerinde yer alan proje ekibinin fikir ve görüşleri alınmıştır. Verimlilik, üretkenlik ve kalite sorularının yanında fazla mesainin kişiler üzerindeki etkileri de incelendiğinden dolayı kişisel bilgiler ile ilgili sorular da ankette bulunmaktadır.

$\mathrm{Bu}$ amaçla oluşturulan araştırma soruları aşağıdaki gibidir:

1. Katılımcıların kişisel bilgileri ve organizasyon yapısı nedir?

2. Katılımcılara göre fazla mesainin verimliliğe, üretkenliğe, kaliteye etkisi ile ilgili görüşleri nelerdir?

3. Fazla mesainin çalışanlar üzerine etkilerine yönelik görüşleri nelerdir?

\subsection{Yöntem}

Fazla mesainin proje ve proje elemanlarına etkilerinin ortaya çıkartılması için anket soruları oluşturulurken Türkdoğan ve diğerleri tarafından fazla mesainin verimlilik üzerindeki etkilerinin incelendiği 2017'de gerçekleştirilmiş çalışmadan faydalanılmıştır [7]. Literatür taraması sonucunda elde edilen bilgiler doğrultusunda iki alan uzmanı tarafından kapsam geçerliliği değerlendirilen 34 soruluk anket hazırlanmıştır. Anket; ekip çalışanları ile ilgili kişisel bilgiler, organizasyon yapısı, fazla mesainin verimliliğe, üretkenliğe, kaliteye etkisi ve ekip çalışanları üzerindeki kişisel etkileri hakkında bilgi edinme amaçlı sorulardan oluşmaktadır.

Yazılım projelerinde yer alan proje ekibinden fikir ve görüşler almak amacı ile oluşturulan anket, çevrimiçi ortamda "www.onlineanketler.com" internet sitesinde katılımcılara sunulmuştur. 2019 Kasım ayı boyunca çevrimiçi ortamda aktif olan anketin, LinkedIn, Edmodo ve Facebook aracılığı ile katılımcı ağının genişletilmesi sağlanmıştır. Nihai olarak ankete yazılım projelerinde yer alan 180 kişi katılmış ve alınan cevaplar analiz edilmiştir.

Anket çalışması, araştırma konusunun içeriğini belirten açıklama ile başlamaktadır. Anketin ilk bölümünde fazla mesaiye kalan ekip çalışanlarının cinsiyeti, yaşı, medeni hali, varsa çocuk sayısı gibi demografik bilgileri toplanmaktadır. İkinci bölümünde, çalışanın yetkinlikleri, deneyimi, proje ekibindeki görevi, çalıştığ1 sektör, proje yönetiminde kullanılan metodoloji ve günlük çalışma saatini belirlemeye yönelik sorular sorulmuştur. Çalışmanın genel amacı fazla mesainin, çalışanlar ve proje üzerindeki etkilerini gözlemlemek olduğu için anketin diğer bölümlerinde fazla mesai ve fazla mesainin verimlilik, üretkenlik, ekip çalışanları ve projenin kalitesi üzerindeki etkileri konusunda katılımcı görüşlerini ortaya çıkartacak sorular yer almaktadır. Fazla mesaiye yönelik ise katılımcılardan, projenin takvime göre ilerleyip ilerlemediği, takvime göre geç kalındığında fazla mesainin yapılıp yapılmadığı ve fazla mesainin ana sebebini soran soruların cevapları alınmıştır. 
Ankette, iki tane evet/hayır türünde, bir adet 20 maddelik beşli Likert türünde ve 12 tekli seçim listeleri türünde toplam 34 soru tipi yer almaktadır.

Beşli Likert soru türünün cevapları sırası ile "Kesinlikle Katılmıyorum", "Katılmıyorum", "Kararsızım", "Katılıyorum", "Kesinlikle Katılıyorum" şeklindedir. $\mathrm{Bu}$ soruları çözen katılımcıların cevaplarına göre, aritmetik ortalamanın hangi cevap aralığına denk geldiğini belirlemek için, her bir puan aralığı aşağıdaki şekilde hesaplanmıştır:

1 - 1,8 puan aralığı "Kesinlikle Katılmıyorum" cevabına, 1,8 - 2,6 puan aralığı "Katılmıyorum" cevabına, 2,6 - 3,4 puan aralığı "Kararsızım" cevabına, 3,4 - 4,2 puan aralığ 1"Katılıyorum" cevabına, 4,2 - 5 puan aralığı "Kesinlikle Katılıyorum" cevabına denk gelmektedir. $\mathrm{Bu}$ soru tipi için verilen cevapların yorumlanması belirtilen puan aralığına göre yapılmaktadır.

\section{2. Örneklem}

Çalışmanın örneklemini yazılım projelerinde yer alan; yazılım mühendisi, test mühendisi, proje yöneticisi, analist, danışman, kalite güvence uzmanı ve diğer proje ekibi çalışanları oluşturmaktadır. Çalışmada doğru sonuçlara varabilmek adına, anket öncelikle fazla mesai yapılıp yapılmadığı sorusu ile başlamaktadır. Fazla mesai yapmayan katılımcıların anketi ilk soruda sonlandırılmaktadır. Toplamda 180 katılımcının bulunduğu ankette 139 katılımcı fazla mesai yaptığını belirtirken 41 katılımcı ise fazla mesai yapmadığını belirtmiştir. Fazla mesai yaptığını söyleyen 139 kişi içinden 97 katılımcı anket sorularının hepsini cevaplamıştır. Çalışma 97 kişinin cevaplarına göre değerlendirilmiştir. 97 katılımcının 46'sı kadın 51'i erkektir.

\subsection{Bulgular}

Fazla mesainin proje ve ekip çalışanları üzerindeki etkilerini tespit edebilmek amaciyla yapılan ankette 180 kişilik katılımcının \%23'ünün fazla mesai yapmadığ1, \%77'sinin ise fazla mesai yaptı̆̆ tespit edilmiştir.

Ankete katılan 139 kişiden 97'si anketi tamamladığ1 için bundan sonraki oranlar 97 katılımcı üzerinden değerlendirilecektir.

Şekil 2'de görüldüğü gibi fazla mesaiye kalan çalışanların \%47'si kadınlardan, \%53'ü ise erkeklerden oluşmaktadır. Şekillerde bulunan sütunların içinde frekans değerleri verilmiştir. Katılımcıların 26 - 30 yaş arasında yoğunluk gösterdiği ve 51 yaş üstü katılımcının bulunmadığı Şekil 3'te görülmektedir. Kadın katılımcıların oranı 20 - 30 yaşları arasında yoğunluk gösterirken, erkek katılımcıların oranı 26 35 yaşları arasında yoğunluk göstermektedir.

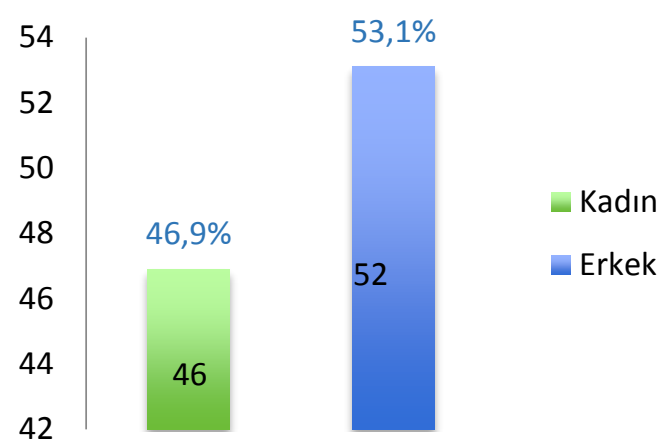

Şekil 2. Cinsiyet oranı
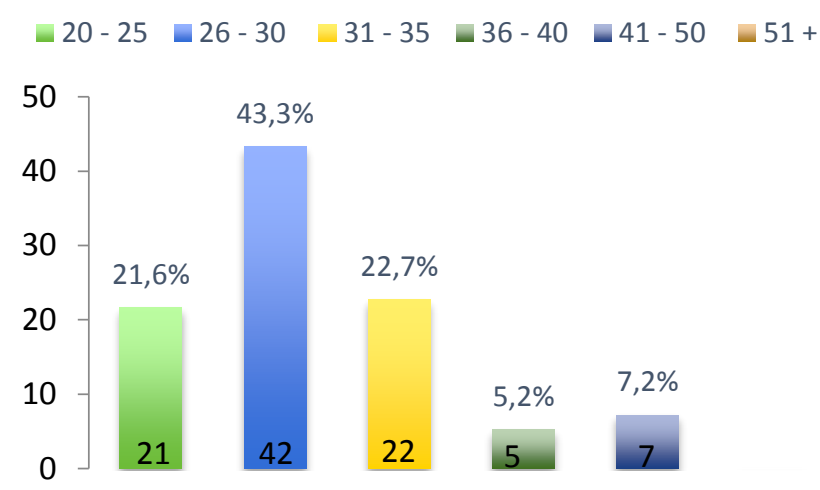

Şekil 3. Yaş oranı

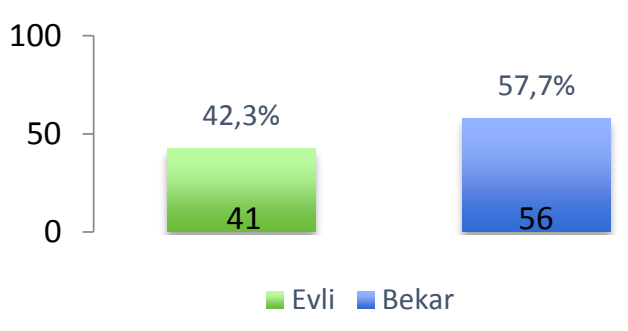

Şekil 4. Medeni hali oranı

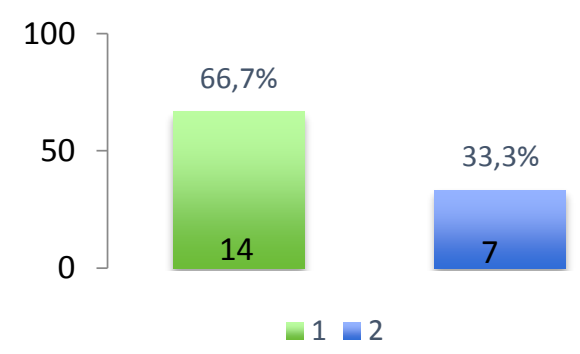

Şekil 5. Çocuk sayısı

Katılımcıların medeni hali ve çocuk sayısını içeren anket soruları ile aile faktörünün fazla mesaide nasıl bir etken olduğu tespit edilmek istenilmiştir. Çalışanların $\% 58$ 'inin bekar \%42'sinin ise evli olduğu Şekil 4'te görülmektedir. Çocuk sayısı sorusu sadece 21 kişi tarafından olumlu yanıtlandığı için Şekil 5'teki yüzdelik ifadeler 21 kişi üzerinden değerlendirilmiştir. 


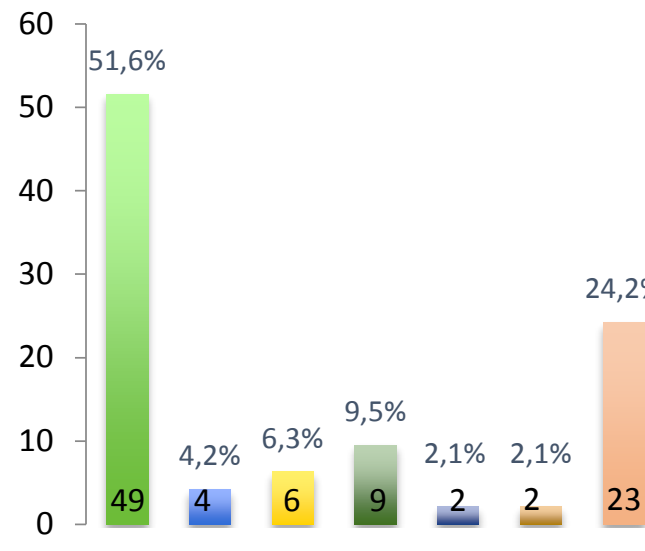

Yazılım Mühendisi
- Test Mühendisi
Proje Yöneticisi
Analist
Danışman
Kalite Güvence Uzmanı
Diğer

Şekil 6. Proje ekibindeki görev oranları

Katılımcıların proje içindeki görevlerinin çok yüksek oranda yazılım mühendisliği olduğu görülmektedir. Şekil 6'da görüldüğü gibi yazılım mühendisliği dışında test mühendisi, analist, proje yöneticileri gibi başka görev tanımları olan ekip üyeleri de katılım sağlamıştır.

Tablo 1. Sektörlerin dağılımı

\begin{tabular}{|l|c|}
\hline \multicolumn{1}{|c|}{ Sektör } & \% \\
\hline Bilgi Teknolojileri & 51,5 \\
\hline Finans & 4,1 \\
\hline Güvenlik Teknolojileri & 1 \\
\hline Oyun Teknolojileri & 1 \\
\hline Sağlık & 4,1 \\
\hline Savunma Sanayi & 10,3 \\
\hline Sigorta & 1 \\
\hline Telekomünikasyon & 6,2 \\
\hline Diğer & 20,6 \\
\hline
\end{tabular}

Tablo 2. Sektördeki deneyim oranları

\begin{tabular}{|c|c|}
\hline Deneyim & \% \\
\hline $1-3$ & 45,4 \\
\hline $4-6$ & 26,8 \\
\hline $7-10$ & 14,4 \\
\hline $11-15$ & 7,2 \\
\hline $16+$ & 6,2 \\
\hline
\end{tabular}

Tablo 1'de sektör dağılımlarının oranları verilmiștir. Ankete katılanların yarısı Bilgi Teknolojileri alanında çalışmaktadır. Diğer yarısı ise sağlık, güvenlik, oyun ve telekomünikasyon gibi yazılım projelerinin geliştirildiği sektörlerde çalışmaktadır.

Sektör deneyiminde yüzdelik dilimi en fazla olan grubun 1 - 3 y1l olduğu Tablo 2'de görülmektedir. Bununla birlikte 1 - 10 y1llık deneyime sahip gruplarda bulunan katılımciların yüksek oranda bilgi teknolojilerinde çalıştıkları, yaklaşık \%70 oranında çevik (agile) yazılım geliştirme metotlarının kullanıldığ 1 , fazla mesainin gönüllü olarak yapıldığ1 ve projenin belirlenen takvime göre geç kalınmasından dolayı yapıldığı görülmektedir.
11 - 16 yıl ve daha üstü deneyime sahip katılımcıların diğer gruba göre daha çok proje yöneticisinin bulunduğu, yüksek oranda çevik yazılım geliştirme metotlarının kullanıldığı, gönüllü olarak fazla mesai yapıldığ 1 ve diğer gruptan farklı olarak operasyon ve uygulama geçişlerine destek olmak için fazla mesaiye kalındığı görülmektedir.

Çalışanların rutin mesai saatlerine ait grafik Şekil 7'de görülmektedir. Büyük çoğunluk 8 saat mesai yaparken 12 saati aşan mesai saatine sahip katılımcılar ise \%3'lük dilimi oluşturmaktadır. Şekil 8'de katılımcıların \%70'inin çevik yazılım geliştirme metotları ile yazılım geliştirdiği görülmektedir.

$$
\text { घ } 8=9-12 \square 12+
$$

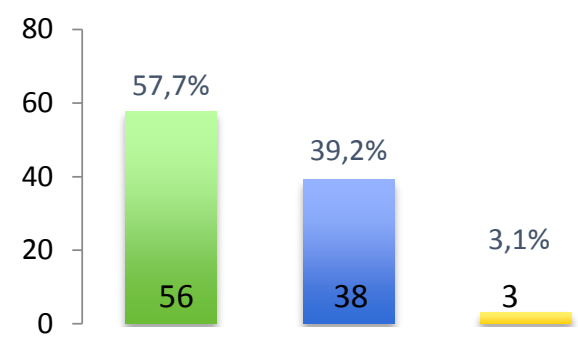

Şekil 7. Mesai saatleri oranı

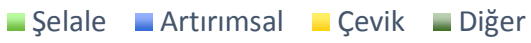

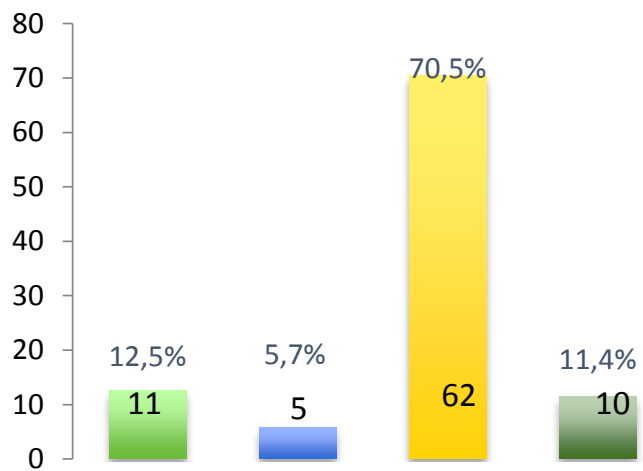

Şekil 8. Metodoloji dağılımı 
12 saat ve daha fazla mesai yapan çalışanların Şelale (Waterfall) metodolojisi ile yazılım geliştirdikleri ve gönüllü olarak fazla mesai yaptıkları gözlemlenmiştir. 8 saat mesai yapan çalışanların \% 75 'inin çevik yazılım geliştirme metodolojisi ile yazılım geliştirdiği ve \%65' gönüllü mesai yaparken \%35'inde kurum fazla mesaiyi zorunlu tuttuğu için fazla mesai yapmaktadır.

Şekil 9'da da görüldüğü gibi katılımcıların çalıştıkları kurumlarda \%88 oranda takvime uygun gidilip gidilmediği kontrol edilmektedir. \%13'lük kısmı oluşturan takvimin takip edilmemesi durumu çalışanlarda belirsizliğin verdiği bir huzursuzluk oluşturmaktadır. Bu \%12'lik dilimde olanların yaklaşık $\%$ 60'1 fazla mesaiye kaldıklarını, bu nedenle dinlenemediklerini ve fazla mesainin psikolojik sorunlara (depresyon, anksiyete vb.) sebep olduğunu düşünmektedirler.

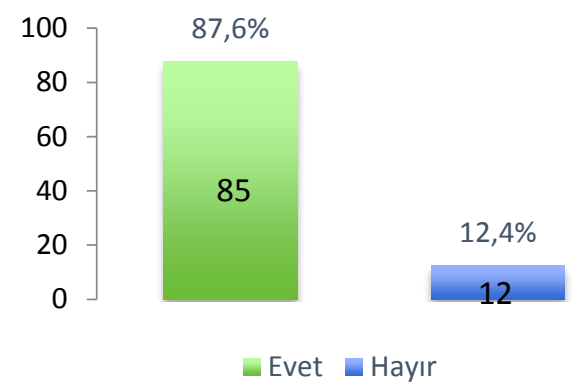

Şekil 9. Takvim takibi oranı
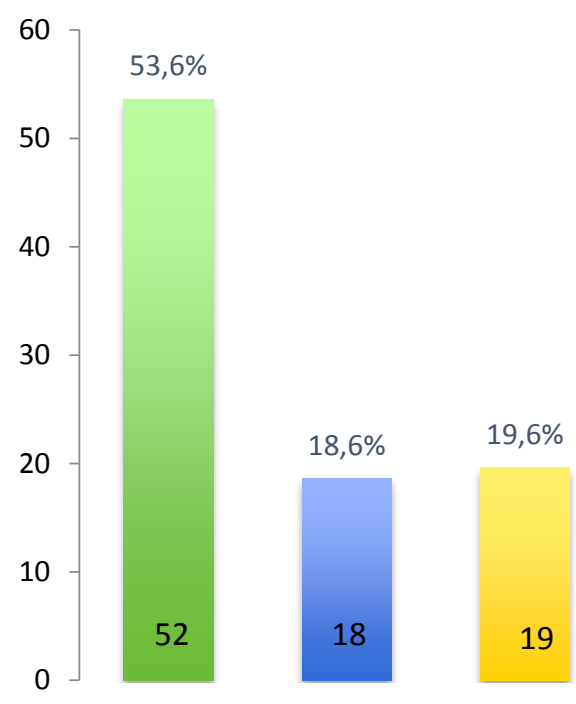

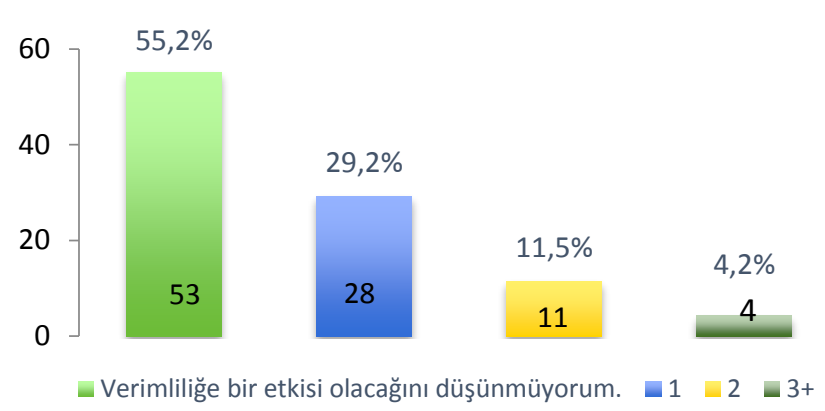

Şekil 10. Fazla mesainin verimliliğe etkisinin dağılımı

Fazla mesaiye gönüllü olarak kalan ve büyük çoğunluğu oluşturan katılımcı oranının \%67 olduğu ve genel sebebin projede planlanan takvime göre geç kalınması olduğu görünmektedir. Ayrıca \%55'lik dilim fazla mesainin verimliliğe etkisi olmadığını düşünürken $\% 35$ 'lik dilim haftada 1 günlük fazla mesainin verimli olabileceğini düşünmektedir. Zorunlu olarak fazla mesaiye kalanlarda da durum benzerlik göstermektedir. $\% 60$ oranında verimliliğe etkisi olmadığı ve \%20 oranında da 1 günlük fazla mesainin verimli olabileceğini düşünmektedir [Şekil 10].

Şekil 11'de görüldüğü gibi fazla mesai yapmadaki sebebin yüksek oranda, projenin beklenen takvimde ilerlememesi olduğu görülmektedir. \%20'lik kesim de operasyon veya uygulama geçişlerine destek olmak amacıyla fazla mesai yaptıklarını ifade etmişlerdir.

Proje için belirlenen takvime göre
geç kalınması
Performans değerlendirmelerinde bir
kriter olması ve çalışılan kurumun
fazla mesai beklentisinin olması
Operasyon veya uygulama geçişine
destek olunması
Fazla mesai ücretine ihtiyaç
duyulması

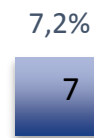

Diğer

Şekil 11. Fazla mesai sebepleri

Tablo 3. Katılımcıların Görüșleri

\begin{tabular}{|c|c|c|c|c|c|c|c|c|c|c|c|c|}
\hline \multirow[t]{2}{*}{ No } & \multirow[t]{2}{*}{ Anket Soruları } & \multicolumn{2}{|c|}{$\begin{array}{c}\text { Kesinlikle } \\
\text { Katılmıyorum }\end{array}$} & \multicolumn{2}{|c|}{ Katılmıyorum } & \multicolumn{2}{|c|}{ Kararsızım } & \multicolumn{2}{|c|}{ Katılıyorum } & \multicolumn{2}{|c|}{$\begin{array}{c}\text { Kesinlikle } \\
\text { Katılıyorum }\end{array}$} & \multirow[t]{2}{*}{ Ortalama } \\
\hline & & $\mathbf{f}$ & $\%$ & f & $\%$ & f & $\%$ & f & $\%$ & $\mathbf{f}$ & $\%$ & \\
\hline 1 & $\begin{array}{l}\text { Fazla mesai için ücret almak beni } \\
\text { motive ediyor. }\end{array}$ & 3 & 3,13 & 8 & 8,33 & 12 & 12,5 & 30 & 31,25 & 43 & 44,79 & 4,06 \\
\hline 2 & $\begin{array}{l}\text { Fazla mesai için ücret almak iş } \\
\text { yorgunluğumu unutturuyor. }\end{array}$ & 11 & 11,46 & 29 & 30,21 & 15 & 15,63 & 21 & 21,88 & 20 & 20,83 & 3,1 \\
\hline
\end{tabular}




\begin{tabular}{|c|c|c|c|c|c|c|c|c|c|c|c|c|}
\hline 3 & $\begin{array}{l}\text { Fazla mesai ücreti aldığımda } \\
\text { gönülllü olarak çalıştığımı } \\
\text { düşünüyorum. }\end{array}$ & 12 & 12,63 & 26 & 27,37 & 23 & 24,21 & 17 & 17,89 & 17 & 17,89 & 3,01 \\
\hline 4 & $\begin{array}{l}\text { Fazla mesai saatlerinde iş } \\
\text { arkadaşlarım tarafindan daha az } \\
\text { bölündüğüm için daha üretken } \\
\text { olduğumu düşünüyorum. }\end{array}$ & 5 & 5,21 & 14 & 14,58 & 10 & 10,42 & 40 & 41,67 & 27 & 28,13 & 3,73 \\
\hline 5 & $\begin{array}{l}\text { Fazla mesai ratlerinde } \\
\text { bulunduğum ortamın daha sessiz } \\
\text { olmasının üretkenliğimi } \\
\text { arttırdığını düşünüyorum. }\end{array}$ & 4 & 4,17 & 14 & 14,58 & 11 & 11,46 & 37 & 38,54 & 30 & 31,25 & 3,78 \\
\hline 6 & $\begin{array}{l}\text { Fazla mesai saatlerinde iş için } \\
\text { danışlacak kişilerin kurumda } \\
\text { olmayışıının üretkenliğimi } \\
\text { azalttığını düşünüyorum. }\end{array}$ & 10 & 10,53 & 19 & 20 & 17 & 17,89 & 39 & 41,05 & 10 & 10,53 & 3,21 \\
\hline 7 & $\begin{array}{l}\text { Fazla mesai } \begin{array}{r}\text { saatlerinde } \\
\text { yorgunluğumun üretkenliğimi } \\
\text { azalttı̆ını düşünüyorum. }\end{array} \\
\end{array}$ & 7 & 7,29 & 7 & 7,29 & 16 & 16,67 & 38 & 39,58 & 28 & 29,17 & 3,76 \\
\hline 8 & $\begin{array}{lr}\text { Fazla mesai } & \text { yapılan günden } \\
\text { hemen sonraki gün mesai saatleri } \\
\text { içerisindeki } & \text { üretkenliğimin } \\
\text { olumsuz } & \text { etkilendiğini } \\
\text { düșünüyorum. } & \\
\end{array}$ & 1 & 1,04 & 12 & 12,5 & 14 & 14,58 & 38 & 39,58 & 31 & 32,29 & 3,9 \\
\hline 9 & $\begin{array}{l}\text { Art arda yapılan fazla mesailerin, } \\
\text { mesai saatleri } \quad \text { içerisindeki } \\
\text { üretkenliğimi } \\
\text { etkilediğini düsünüyorum. }\end{array}$ & 1 & 1,04 & 1 & 1,04 & 7 & 7,29 & 40 & 41,67 & 47 & 48,96 & 4,36 \\
\hline 10 & $\begin{array}{l}\text { Fazla mesai saatleri içerisinde } \\
\text { daha fazla hata yaptığımı } \\
\text { düşünüyorum. }\end{array}$ & 6 & 6,25 & 36 & 37,5 & 25 & 26,04 & 18 & 18,75 & 11 & 11,46 & 2,92 \\
\hline 11 & $\begin{array}{l}\text { Fazla mesai yaptığım gün } \\
\text { (ler)den sonra mesai saatlerinde } \\
\text { hata yapma ihtimalimin arttı̆ı̆ını } \\
\text { düşünüyorum. }\end{array}$ & 4 & 4,17 & 17 & 17,71 & 30 & 31,25 & 31 & 32,29 & 14 & 14,58 & 3,35 \\
\hline 12 & $\begin{array}{l}\text { Fazla mesaiye kaldı̆̆ımda } \\
\text { dinlenemediğimi düşünüyorum. }\end{array}$ & 2 & 2,08 & 5 & 5,21 & 8 & 8,33 & 42 & 43,75 & 39 & 40,63 & 4,16 \\
\hline 13 & $\begin{array}{l}\text { Fazla mesainin fiziksel sağlık } \\
\text { sorunlarına sebep olduğunu } \\
\text { düşünüyorum. }\end{array}$ & 3 & 3,13 & 7 & 7,29 & 18 & 18,75 & 37 & 38,54 & 31 & 32,29 & 3,9 \\
\hline 14 & $\begin{array}{l}\text { Fazla mesainin } \\
\text { artırdığını düşünüyorum. }\end{array}$ & 4 & 4,17 & 12 & 12,5 & 9 & 9,38 & 39 & 40,63 & 32 & 33,33 & 3,86 \\
\hline 15 & $\begin{array}{l}\begin{array}{l}\text { Fazla mesainin psikolojik } \\
\text { sorunlara } \\
\text { anksiyete...vb.) sebep olduğunu } \\
\text { düşünüyorum. }\end{array} \\
\end{array}$ & 4 & 4,17 & 10 & 10,42 & 20 & 20,83 & 34 & 35,42 & 28 & 29,17 & 3,75 \\
\hline 16 & $\begin{array}{lc}\text { Fazla mesaiye } & \text { kalmanın } \\
\text { motivasyonu } & \text { olumsuz } \\
\text { etkilediğini düşünüyorum. }\end{array}$ & 5 & 5,21 & 12 & 12,5 & 14 & 14,58 & 34 & 35,42 & 31 & 32,29 & 3,77 \\
\hline 17 & $\begin{array}{l}\text { Gönüllü olarak yapılan fazla } \\
\text { mesainin motivasyonumu } \\
\text { düşürmediğini düşünüyorum. }\end{array}$ & 2 & 2,08 & 11 & 11,46 & 16 & 16,67 & 45 & 46,88 & 22 & 22,92 & 3,77 \\
\hline 18 & $\begin{array}{l}\text { Fazla mesainin zararlı } \\
\text { alışkanlıklara (sigara, alkol, kötü } \\
\text { beslenme,..vb.) yönelmeye sebep } \\
\text { olduğunu düşünüyorum. }\end{array}$ & 14 & 14,58 & 29 & 30,21 & 13 & 13,54 & 25 & 26,04 & 15 & 15,63 & 2,98 \\
\hline 19 & $\begin{array}{l}\text { Fazla mesaiye kalmamın aile } \\
\text { yaşamımı olumsuz etkilediğini } \\
\text { düşünüyorum. }\end{array}$ & 5 & 5,21 & 7 & 7,29 & 13 & 13,54 & 34 & 35,42 & 37 & 38,54 & 3,95 \\
\hline 20 & $\begin{array}{l}\text { Fazla mesaiye kalmamın sosyal } \\
\text { yaşamımı olumsuz etkilediğini } \\
\text { düşünüyorum. }\end{array}$ & 4 & 4,17 & 6 & 6,25 & 3 & 3,13 & 39 & 40,63 & 44 & 45,83 & 4,18 \\
\hline
\end{tabular}

Tablo 3'te katılımcıların görüşleri yer almakta ve 4,36 ile "Art arda yapılan fazla mesailerin, mesai saatleri içerisindeki üretkenliğimi olumsuz etkilediğini düşünüyorum.” görüşü en yüksek ortalamaya sahiptir. 4,18'lik ortalama ile "Fazla mesaiye kalmamın sosyal yaşamımı olumsuz etkilediğini düşünüyorum" görüşüne de yüksek oranda destek verilmiştir. 2 ve 3 . sorularda, çalışanların fazla mesai ücreti alması durumunda nasıl etkilendikleri ölçülmek istenmiş ve sonucun "Kararsızım" olduğu ortaya çıkmıştır. Fakat 1. soruda ücret almanın çalışanları motive ettiği görülmektedir. $\mathrm{Bu}$ durumda fazla mesai ücretinin çalışanların yorgunluklarını unutturmadığı ve gönüllü çalışmaya teşvik etmediği fakat kısa vadede motive edebildiği sonucuna varılabilir. 10 ve 11 . sorular yazılımın kalitesine yönelik hata yapma oranını 
sorgulamakta olup sonuç "Kararsızım" çıkmıştır. Bu da fazla mesainin hata oranını yüksek miktarda arttırmadığını göstermektedir.

6. soruda katılımcilar, fazla mesai sebebiyle danışılacak kişilerin kurumda olmamasının üretkenliğe etkisinde "Kararsız" olduklarını, 4 ve 5. sorularda ise iş arkadaşları tarafından daha az bölündükleri için daha üretken oldukları, sessizliğin üretkenliği arttırdığı fikrine katıldıklarını ifade etmişlerdir. Bu sonuçlardan yola çıkarak çalışanların daha sessiz ve tenha bir iş ortamında daha üretken ve verimli çalışabildikleri söylenebilir.

7 ve 8 . Sorular çalışanların üretkenliklerine yönelik sorulardır. Bu sorularda çalışanlar mesai sonrasındaki günlerde ve fazla mesainin verdiği yorgunluk sebebiyle üretkenliklerinin olumsuz etkilendikleri fikrine katıldıklarını belirtmişlerdir. Bu durum aslında mesai saatleri içinde daha kısa sürede bitirilebilecek hedeflerin daha uzun süreler alabileceğine işaret etmektedir.

$12,13,14,15,16,19$ ve 20 . sorularda çalışanların fazla mesainin fiziksel ve psikolojik sorunların olasıllı̆ını arttırdığı, beraberinde sosyal yaşamın ve aile yaşantısının da olumsuz etkilendiği fikrine katıldıklarını belirtmişlerdir. Ayrıca fazla mesai sebebiyle streslerinin arttığı ve motivasyonlarının da düşmesi konusunda ortak fikre sahiptirler. Kurumun fazla mesaiden beklentisi; çalışanların stres, motivasyon düşüklüğü, sağlık ve çevrelerine yansıyan olumsuz etkileri ile baş etmeye çalışması sebebiyle projeye yansımamaktadır. Hatta bu durum takvimin daha da uzamasina sebep olabilir.

Evli ve bir çocuk sahibi çalışanlar fazla mesainin, çok yüksek oranda, aile yaşantısını olumsuz yönde etkilediğini, streslerinin arttığını ve dinlenemediklerini belirtmişlerdir. Ayrıca bekar çalışanlar da fazla mesai sebebiyle sosyal yaşantılarının olumsuz etkilendiğini ve dinlenemediklerini ifade etmişlerdir.

Çalışanlar gönüllü olarak mesai yaptıklarında motivasyonlarının düşmediğini 17 . soruda belirtmişler ve ayrica fazla mesai yaparken daha fazla hata yaptıklarını soran 10. soruya da katılmadıklarını ifade etmişlerdir.

18. soruya bakıldığında sigara, alkol vb. kötü alışkanlıklara eğilimde çalışanlar kararsız olduklarını belirtmişlerdir.

\section{SONUÇ VE TARTIŞMA}

Araştırmada fazla mesainin yapılma sebepleri ve yazılım projeleri üzerindeki verimlilik etkisi çalışanların görüşleri yardımıyla incelenmiş̧ir. Türkdoğan ve diğerleri tarafindan fazla mesainin verimlilik üzerindeki etkilerinin incelendiği 2017'de gerçekleştirilmiş çalışmada da fazla mesainin, aile ve sosyal ilişkilerde sıkıntılara neden olduğu, fiziksel ve psikolojik rahatsızlıkların olasılığını arttırdığı ve üretkenliğin azaldığı konularında benzer sonuçlar elde edilmiştir [7]. Bu çalışmada, genç bir katılımcı kitlesi üzerinden araştırma yapılmıştır. Dolayısıyla bu çalışma yazılım sektöründe çalışan genç kitlenin görüşlerini yansıtması açısından önemlidir.

Fazla mesai yapılma sebeplerine bakıldığında katılımcıların \%54'ü belirlenen takvime göre geç kalması, \%20'si operasyona ve uygulama geçişlerine destek olmas1, \%19'u da performans değerlendirmelerinde bir kriter olması sebebiyle fazla mesai yaptıklarını belirtmiş̧lerdir. Çoğunlukla takvime göre geç kalınması, daha gerçekçi bir takvimlendirme, işin yetkinlikler göz önüne alınarak doğru kişilere atanması, doğru proje yönetim metodolojisinin seçilmesi gibi konuların üzerinde durulması gerektiğini göstermektedir.

Sonuçlara göre; üretkenlik, yazılım kalitesi, çalışanlar üzerindeki kişisel etkiler çerçevelerinden verimlilik etkilerinin incelendiği fazla mesainin istenen getiriyi sağlamadığı görülmüştür. İstenen getiriyi sağlamamasının yanı sıra yazılımın kalitesi, çalışan kişilerin zihinsel ve fiziksel sağlıklarını tehdit etmesi, üretkenliği düşürmesi, sosyal ve aile yaşantısının kötü etkilenmesi gibi olumsuz etkilerinin bulunmasından dolayı bir yazılım projesi için toplam verimlilik olarak iyi sonuçlar ortaya çıkarmadığı görülmektedir. Fazla mesainin planlı bir şekilde yapılması gerektiği durumlar dışında fazla mesai yapmamak daha iyi bir seçim olarak karşımıza çıkmaktadır.

Üretkenlik çerçevesinden baktığımızda, fazla mesai yapılan saatlerde çalışanların normal mesai saatlerine göre daha az üretken olduğu görülmektedir. Katılımcıların \%70'i yorgunluk sebebiyle, \%52'si iş için danışlacak kişilerin kurumda olmayışı sebebiyle fazla mesai yapılan saatlerde daha az üretken olduklarını belirtmişlerdir. Fazla mesainin akabindeki mesai saatleri üzerinde de olumsuz etkisi bulunmaktadır. Araştırma sonuçlarına göre katılımcıların \%72'si fazla mesai yapılan günden hemen sonraki gün üretkenliklerinin önemli bir oranda düştüğünü belirtirken $\% 15$ ' $\mathrm{i}$ üretkenliklerinin değişmediğini belirtmişlerdir. Bu durum da fazla mesai yapan çalışanlar aynı saat miktarında normal mesai saatlerinde çalışırlarsa üretkenlik artışı fazla mesai yapılarak elde edilecek artıştan daha fazla olacaktır. Ayrıca katılımcıların \%90'lık kısmı art arda yapılan fazla mesainin üretkenliği olumsuz yönde etkilediğini düşünmektedir.

Kalite çerçevesinden baktığımızda, katılımcıların $\% 47$ 'si fazla mesai yapılan günlerin akabindeki mesai saatlerinde, hata yapma ihtimallerinin önemli ölçüde arttığını belirtirken \%22'lik bir kısmı fazla mesainin hata yapma olasılığına bir etkisinin olmadığı görüşündedir. 
Dinlenme ve rahatlama eksikliklerinin öncelikle vücudun çeşitli yerlerinde ağrı oluşumuna sonrasında ise anksiyete ve depresyon gibi zihinsel sağlık problemlerine sebep olduğu bilinmektedir [11]. Bu bağlamda fazla mesainin ekip üyeleri üzerindeki kişisel etkilerine bakıldığında, çalışanların fiziksel ve zihinsel sağlıkları üzerinde olumsuz etkiler oluşturduğu söylenebilir. Katılımcıların \%84'ü fazla mesai sebebiyle dinlenme eksikliği yaşadıklarını, \%74’ü stres seviyelerinin arttığını, \%67'si da motivasyon düşüklüğü yaşadıklarını belirtmişlerdir. Ayrıca katılımcıların \%65'i fazla mesainin fiziksel ve zihinsel sağlık problemlerini tetiklediği görüşündedir.

Günlük çalışma saatlerinden fazla çalışılan saatler, sosyal yaşam saatlerinden çaldığı için doğrudan çalışanların yaşamlarını da etkilemektedir. Katılımcıların \%74'ü fazla mesai sebebiyle aile yaşantısının, \%86'sı da sosyal yaşantısının olumsuz etkilendiği yönünde görüş bildirmişlerdir. Olson ve diğerleri çalışmalarında proje baskısı veya yetersiz uyku kaynaklı huzursuzlukların aile içinde büyük çatışmalara dönüşebileceğini ve eşler arasında bir rol çatışması yaşatabileceğine dikkat çekmiş, aşırı ve zorunlu fazla mesainin aile hayatını olumsuz yönde etkilediğini belirtmişlerdir [1]. Bu bağlamda sonuçlara bakıldığında zorunlu fazla mesaiye kalan evli çalışanların \%92'si, evli ve çocuklu çalışanların ise tamamı aile ve sosyal yaşamlarının fazla mesai sebebiyle olumsuz etkilendiğini belirtmişlerdir. $\mathrm{Bu}$ da özellikle evli ve çocuklu çalışanlar için fazla mesai ile ilgili düzenlemenin bir ihtiyaç haline geldiğini göstermektedir.

Fazla mesainin proje ekibine, dolayısıyla projenin verimliliği üzerinde olumsuz etki ettiği Frangos'un yaptığı çalışmada da ortaya konmakta ve gerçekleştirdiğimiz çalışma sonuçları ile paralellik göstermektedir. Frangos yaptığı çalışmasında, aşırı çalışmanın yazılım personellerinin verimliliğini düşürdüğü, yazılım projelerinde ortaya çıkacak ürün için harcanan zamanda, kişinin günde belirli saat boyunca üretken yani konsantrasyon halinde kalabildiği belirtilmiştir [4].

Kuutila ve arkadaşlarının gerçekleştirdiği çalışmada ise; zaman baskısının, artan motivasyon gibi yazılım geliştiricileri üzerinde olumlu etkileri olabileceği gibi, bunun da olumsuz etkileri olduğu gösterilmiştir. Çalışanlarda, artan stres ve mutsuzluğun sonunda depresyon ve tükenmişliğe yol açabileceğini belirtmişlerdir. $\mathrm{Bu}$ çalışmanın sonuçları ile çalışmamızın sonuçlarının paralellik gösterdiği görülmektedir. Gerçekleştirilen çalışmada da katılımcilar fazla mesainin fiziksel ve psikolojik sorunların olasılığını ve streslerini artırdığı yönünde görüş bildirmişlerdir. Kuutila ve arkadaşları bu durumla baş etmek için özellikle, Kanban ve Scrum gibi fazla mesaiyi azaltan çevik yöntemleri önermektedir. Ayrıca, bireylerin bilgisinin ve yöneticilerin becerilerinin yüksek olduğu bir ekipte çalışmanın, zaman baskısının ekip üyeleri üzerindeki olumsuz etkilerini azaltabileceğini belirtmişlerdir. Özellikle artan çalışma saatleri söz konusu olduğunda kullanılan yazılım geliştirme yönteminin yeniden gözden geçirilmesi ve daha verimli olabilecek Scrum gibi yöntemlere başvurulması daha etkili sonuçlar ortaya çıkartabilmektedir [12].

Türkdoğan ve arkadaşları da yazılım mühendisliği projelerinde fazla mesainin çalışanlarda verimliliği, aile yaşantısını, sosyal iletişim alanlarını ve yazılım kalitesini olumsuz etkilediğini belirtmektedirler [7]. Çalışmamızın sonuçlarının Türkdoğan ve arkadaşlarının aldığı sonuçlar ile paralellik gösterdiği görülmektedir.

Graziotin ve arkadaşlarının gerçekleştirdiği çalışmaya göre, yazılım geliştiricilerde, geliştiricinin dışındaki faktörlerden kaynaklanan mutsuzluğun en s1k ikinci nedeni olarak zaman baskısı görülürken, birinci mutsuzluk nedeni "problem çözmede takılı kalmak" olarak ortaya konmuştur [13]. Çalışmamızın sonuçlarında çalışanları duygusal ve fiziksel olarak yıpratan bir durum olarak zaman baskısının bir sonucu olarak yaşadıkları fazla mesai faaliyetlerinin bir mutsuzluk nedeni olarak belirtilmesi mümkündür.

Giderek daha yoğun ve karmaşık projeler ile uğraşmak durumunda kalınan yazılım sektöründe, fazla mesainin düşünülen verimliliği sağlayamadığı görülmektedir. Yazılım proje yöneticilerinin fazla mesai yerine, yeni yazılım geliştirme metodolojilerini projelerine entegre etme, esnek çalışma saatleri gibi çalışanlarına farklı alternatifler sunma, iş yerinde geçirilen zamanı daha üretken hale getirme gibi farklı çalışma modellerine yönelmeleri hem çalışanlar hem de yöneticiler için daha faydalı çözümler sunabilecektir.

\section{KAYNAKLAR}

[1] Olson, B., \& Swenson, David. (2011) Overtime effects on project team effectiveness. In The Midwest Instruction and Computing Symposium, 2011.

[2] Putnam, L. H. (1978). A general empirical solution to the macro software sizing and estimating problem. IEEE transactions on Software Engineering.

[3] Reichelt, K., \& Lyneis, J. (1999). The dynamics of project performance: benchmarking the drivers of cost and schedule overrun. European management journal.

[4] Frangos, S. A. (1997). Motivated humans for reliable software products. In Reliability, Quality and Safety of Software-Intensive Systems (pp. 83-91). Springer, Boston, MA.

[5] Verner, J., Sampson, J., \& Cerpa, N. (2008, June). What factors lead to software project failure?. In 2008 Second International Conference on Research Challenges in Information Science (pp. 71-80). IEEE. 
[6] Wang, Y., \& Shi, H. (2009, May). An exploratory study on china's software engineers' unpaid overtime working. In Proceedings of the special interest group on management information system's 47th annual conference on Computer personnel research (pp. 209-214).

[7] Türkdoğan, N., Güceğlioğlu, S., Demirörs, O. (2017). Yazılım Mühendisliği Projelerinde Fazla Mesainin Verimlilik Üzerine Etkileri. 11. Ulusal Yazılım Mühendisliği Sempozyumu.

[8] Mann, C., \& Maurer F. (2005) A Case Study on the Impact of Scrum on Overtime and Customer Satisfaction. In 2005 IEEE Proceedings of the Agile Development Conference.

[9] Akula, B., \& Cusick, J. (2008) Impact of Overtime and Stress on Software Quality Conference: The 4th International Symposium on Management, Engineering, and Informatics.

[10]Edholm, H., Lidström, M., Steghöfer, J. (2017) Crunch Time: The Reasons and Effects of Unpaid
Overtime in the Games Industry. 2017 IEEE/ACM 39th International Conference on Software Engineering: Software Engineering in Practice Track.

[11] Nishikitani, M., Nakao, M., Karita, K., Nomura, K. \& Yano, E. (2005) Influence of overtime work, sleep duration, and perceived job characteristics on the physical and mental status of software engineers.

[12] Kuutila, M., Mäntylä, M., Farooq, U., \& Claes, M. (2020). Time pressure in software engineering: A systematic review. Information and Software Technology, 106257.

[13] Graziotin, D., Fagerholm, F., Wang, X., \& Abrahamsson, P. (2017, June). On the unhappiness of software developers. In Proceedings of the $21 \mathrm{st}$ International Conference on Evaluation and Assessment in Software Engineering (pp. 324333). 